\title{
Social Representations and Public Policy: Influence of the Distance from the Object on Representational Valence
}

\author{
Jimmy Bordarie, Sandrine Gaymard \\ Laboratoire de Psychologie des Pays de la Loire, Universitéd'Angers, Angers, France \\ Email: jimmy.bordarie@hotmail.fr
}

Received 11 September 2015; accepted 27 September 2015; published 30 September 2015

\begin{abstract}
Theory: Our research is based on the social representations theory (Moscovici, 1961) [1] as an interpretation grid to understand reality. These representations constitute a way to defend social positions towards a social object. We are interested in the concept of distance from the object (Abric, 2001) [2] to study individuals' feelings towards a social object. People can feel concerned and close to it, or not concerned and distant from it. We assume this link impacts the representational elements' valence. By applying it to the urban mobility public policy of $30 \mathrm{kph}$, we inscribe it into an applied approach with the aim of helping urban planners, politicians and associations to understand social acceptability of this measure. Method: 129 young French drivers (mean age: 22.4; SD: $3.8 ; 78 \%$ are women and $22 \%$ are men) replied to a questionnaire to determine the individuals' distance from the object and the social representation of $30 \mathrm{kph}$. Results: A T test highlights the significant influence of the distance from the object on the representational elements' valence. Depending on individuals' feelings, social representation is focused upon pro-social or negative aspects. Gender seems to have a minor impact, whereas the regular mode of transport seems to influence the representation. Applications: Our results clearly give information to build efficient awareness campaigns (Bordarie \& Gaymard, 2015) [3]. They can also provide indications for urban planners to implement $30 \mathrm{kph}$ zones, highlighting the flexibility of practices (Bordarie \& Gaymard, 2015) [4].
\end{abstract}

\section{Keywords}

Social Representations, Distance from the Object, Valence, $30 \mathrm{kph}$, Acceptability

\section{Framework}

\section{Social Representations, Valence and Distance from the 0 bject}

Social representations (Moscovici, 1961) [1] are defined as knowledge of common sense (Jodelet, 1991) [5] and constitute a reading grid for people (Moliner, 1988) [6] in order to analyse the world. They appear through two processes: objectification and anchorage (Moscovici, 1961) [1]. The first one refers to the creation of a figurative core, an image, which allows people to understand and appropriate a concept making it more concrete. If the 
objectification process seems to be a process of knowledge creation about the social object, the anchoring resembles an integration of this knowledge in individuals' reality. Indeed, the anchoring consists in the appropriation of the new knowledge and object, giving it some sense, and generating stances (Doise, 1986, 1992) [7] [8]. This integration rests on classification, categorization and denomination mechanisms in order to make the object familiar. The selection of information participates in the objectification process giving a positive or negative image of the object. We could speak about the positive or negative balance, or more generally we will use the valence of the representation. The representational valence appears equal to the cause and the consequence of the link that individuals have with the object. This link constitutes an important element for the understanding of individuals' representation. However, there are very few studies interested in this link. Rouquette $(1994,1997)$ [9] [10] evokes the importance of individuals' implication towards the object and distinguishes three factors: valorisation, identification and action capacity. These three factors appear to be important variables in order to understand the representation and individuals' practices toward an object. By questioning the nature of the object/subject relationship (Abric \& Tafani, 1995) [11], Abric (2001) [2] theorises the concept of "distance from the object”. Dany and Abric (2007) [12] published one of the rare studies testing this concept. These authors studied the relationship between individuals and cannabis by questioning their beliefs and practices. They highlighted the role of those factors in the distance from the object and showed with a Principal Component Analysis how they influenced the structure of cannabis' social representation. Other aspects such as normative aspects are important in the dynamics of social representation (Flament, 1999; Gaymard, 2003) [13]-[16]. Indeed, the role of parent or peer models has been demonstrated in several studies, especially in the mobility and road safety framework (Bordarie \& Gaymard, 2014; Gaymard, 2009; Gaymard \& Bessin, 2014) [17]-[19]. These aspects could participate in the understanding of social regulation phenomena (Doise, 1986, 1992) [7] [8]. The insertion in reality directly refers to the anchoring process (Moscovici, 1961) [1] and constitutes essential data in social representations' studies. The distance from the object proposes an interesting perspective to understand social representations and practices, their insertion in individuals' daily life and their potential transformations. The distance from the object constitutes an index of representation and dynamics of practices. It is a way to understand the differences in a population, both for highlighting the link individuals/objects and emphasizing the representational valence.

\section{Methodology}

\subsection{Procedure}

Students motorists from Angers filled out a questionnaire anonymously displayed on an online platform.

\subsection{Population}

129 individuals replied to the questionnaire. $78 \%$ of women and $22 \%$ of men constitute the population. They are 22.4 years old (standard deviation: 3.8 ).

\subsection{Tool}

We created a questionnaire split into two parts. The first one refers to the measure of distance from the object, by using the factors found in the literature (for example, Gaymard, 2007) [20]. We added questions on normative aspects and used questions on habits to study practices. The second part deals with the social representation of $30 \mathrm{kph}$. For each question, individuals had to choose a modality from 1 (not agree at all) to 6 (totally agree). We chose pairs of scales to insure a clear answer, positive or negative from subjects, in order to measure the valence of the different items. We also chose positive modalities to avoid the negative value impact (Schwarz, Knäuper, Hippler, Noelle-Neumann, \& Clark, 1991) [21].

\section{Results}

\subsection{Distance from the Object}

We measured the distance from the object using several variables. Mixing the different conclusions presented in the literature, we used various components such as attitude, perceived social norm from parent model and peer model, perceived capacity, personal implication and perceived importance (Rouquette, 1995) [22]. We also used 
people’ practices and habits (Abric, 2001; Dany \& Abric, 2007) [2] [12] with some variables of the self-report habits index (Verplanken \& Orbell, 2003) [23]. We tested the behaviour frequency, automaticity, the perceived difficulty, the identification with the behaviour and since when they began to have the expected behaviour. We finally add a question on the intention people have to realize the behaviour and comply with the $30 \mathrm{kph}$. Our tool to evaluate the distance from the object is composed of 12 variables divided into two components such as social cognitive aspects and habit aspects. The Cronbach alpha indicates a good reliability ( $\alpha=0.929$ ), higher than the minimum level of 0.70 (Nunnaly, 1978) [24]. Every item appears to be significant and necessary to optimize the Cronbach alpha. From the individuals' average, we can create two groups (cf. Table 1) by dividing individuals who "feel concerned" (object distance higher than the mean) and individuals who "don't feel concerned" (object distance lower than the mean).

\subsection{Representational Valence}

We did a mean comparison test from the results for each item.

Our two groups manifest two different social representations with significant differences for many items. Individuals close to the object, who feel concerned, consider the items calm, facility, promote bike use, useful, ecology, cohabitation, respect of others, quality of life, saving money and space sharing $(\mathrm{p}<0.001)$ are directly related to the $30 \mathrm{kph}$. The others think the opposite (cf. Table 2). All those elements refer to pro-social aspects and constitute positive aspects of $30 \mathrm{kph}$.

The results highlight differences between the two groups. Nevertheless, others differences exist even if they don't oppose the two groups. Both of them do agree with the fact that some items are related or not to the $30 \mathrm{kph}$ but the value of their harmony is significantly different. For instance, concerned and not concerned people do agree to say that caution, safety, respect of rules, schools, slowness, increase of travel time $(p<0.000)$, presence of children in the car $(\mathrm{p}<0.02)$, pedestrians $(\mathrm{p}<0.03)$ and cyclists $(\mathrm{p}<0.05)$ are related to $30 \mathrm{kph}$. And yet, their level of agreement is statistically different. Thus, we note that the negative aspects like slowness and travel time increase imply a level of agreement higher for the group distant from the object. On the other hand, all the others elements suggest a higher agreement of concerned people (cf. Table 3). It means that negative aspects are more important and have more impact on the distant group's representation. The close group's representation is more impacted by conditional aspects and the consideration of others.

\section{Discussion}

Results suggest that the distance from the object (Abric, 2001) [2] is particularly interesting in order to analyse the valence of social representations. The index we measured appears to be a relevant way to measure people's "degree of concern" towards a social object (Rouquette, 1995) [22]. We include normative aspects of parent model and peer model in our tool. These aspects impact the social representation construction (Bordarie \& Gaymard, 2014; Flament, 1999, 2001; Gaymard, 2003, 2009; Gaymard \& Andrés, 2009) [13] [15] [17] [18] [25] [26] but they are often not taken into account. By using intention and habits as variables, we also optimized the distance from the object index. Thus, we could better evaluate the link between individuals and the social object of $30 \mathrm{kph}$. We saw this index was useful to analyse and predict the representational valence.

The words with the most influence for concerned people are safety, children, pedestrians and danger while slowness, police, children and danger have the most influence for not concerned people. We can see some similarities in both representations with the presence of children and danger. Nevertheless, the representation differs according to the importance our two groups give to safety and slowness to define $30 \mathrm{kph}$ zones. Moreover, some pro-social aspects (calm, facility, promote bike use, useful, ecology, cohabitation, respect for others, quality of life, saving money and space sharing) are specific to people who feel concerned by the $30 \mathrm{kph}$.

Our study emphasizes the role of constraining aspects (police, fines, urban design, danger, obligation) in the representation of $30 \mathrm{kph}$. Both of our two groups related them to the $30 \mathrm{kph}$. The interest of our study lies within the fact that in spite of these negative aspects, a part of our population prefers to focus on more positive aspects.

Table 1. Distribution of individuals according to the object distance index.

Low index of object distance (lower than 3.5) (don't feel concerned) 82

High index of object distance (higher than 3.5) (feel concerned) 
Table 2. Mean test for the items with significant disagreement between our two populations.

\begin{tabular}{|c|c|c|c|c|c|c|}
\hline & & \multicolumn{2}{|c|}{ Levene Test } & \multicolumn{3}{|c|}{ T-Test } \\
\hline & & $\mathrm{F}$ & Sig. & $\mathrm{t}$ & ddl & Sig. (bilateral) \\
\hline \multirow{2}{*}{ Calm } & If equal variance & 1.199 & 0.276 & -5.235 & 127 & 0.000 \\
\hline & In unequal variance & & & -5.385 & 104.315 & 0.000 \\
\hline \multirow{2}{*}{ Facility } & If equal variance & 4.875 & 0.029 & -6.706 & 127 & 0.000 \\
\hline & In unequal variance & & & -6.183 & 74.952 & 0.000 \\
\hline \multirow{2}{*}{ Promote bike use } & If equal variance & 0.464 & 0.497 & -4.243 & 127 & 0.000 \\
\hline & In unequal variance & & & -4.229 & 95.026 & 0.000 \\
\hline \multirow{2}{*}{ Useful } & If equal variance & 0.008 & 0.928 & -5.332 & 127 & 0.000 \\
\hline & In unequal variance & & & -5.255 & 91.788 & 0.000 \\
\hline \multirow{2}{*}{ Ecology } & If equal variance & 1.060 & 0.305 & -5.702 & 127 & 0.000 \\
\hline & In unequal variance & & & -5.841 & 103.076 & 0.000 \\
\hline \multirow{2}{*}{ Cohabitation } & If equal variance & 3.626 & 0.059 & -5.672 & 127 & 0.000 \\
\hline & In unequal variance & & & -5.985 & 111.772 & 0.000 \\
\hline \multirow{2}{*}{ Respect of others } & If equal variance & 0.044 & 0.835 & -5.521 & 127 & 0.000 \\
\hline & In unequal variance & & & -5.421 & 90.766 & 0.000 \\
\hline \multirow{2}{*}{ Quality of life } & If equal variance & 1.707 & 0.194 & -5.434 & 127 & 0.000 \\
\hline & In unequal variance & & & -5.184 & 83.051 & 0.000 \\
\hline \multirow{2}{*}{ Saving money } & If equal variance & 0.934 & 0.336 & -3.546 & 127 & 0.001 \\
\hline & In unequal variance & & & -3.439 & 87.318 & 0.001 \\
\hline \multirow{2}{*}{ Space sharing } & If equal variance & 1.478 & 0.226 & -5.928 & 127 & 0.000 \\
\hline & In unequal variance & & & -6.204 & 109.402 & 0.000 \\
\hline
\end{tabular}

Table 3. Mean test for the consensual items with significant difference in the level of harmony.

\begin{tabular}{|c|c|c|c|c|c|c|}
\hline & & \multicolumn{2}{|c|}{ Levene Test } & \multicolumn{3}{|c|}{ T-Test } \\
\hline & & $\mathrm{F}$ & Sig. & $\mathrm{t}$ & ddl & Sig. (bilateral) \\
\hline \multirow{2}{*}{ Caution } & If equal variance & 6.485 & 0.012 & -4.495 & 127 & 0.000 \\
\hline & In unequal variance & & & -5.138 & 126.896 & 0.000 \\
\hline \multirow{2}{*}{ Safety } & If equal variance & 3.924 & 0.050 & -4.065 & 127 & 0.000 \\
\hline & In unequal variance & & & -4.410 & 119.102 & 0.000 \\
\hline \multirow{2}{*}{ Cyclists } & If equal variance & 1.395 & 0.240 & -2.186 & 127 & 0.031 \\
\hline & In unequal variance & & & -2.303 & 111.399 & 0.023 \\
\hline \multirow{2}{*}{ Respect of rules } & If equal variance & 4.507 & 0.036 & -3.643 & 127 & 0.000 \\
\hline & In unequal variance & & & -4.024 & 122.989 & 0.000 \\
\hline \multirow{2}{*}{ Schools } & If equal variance & 4.422 & 0.037 & -3.761 & 127 & 0.000 \\
\hline & In unequal variance & & & -4.035 & 116.312 & 0.000 \\
\hline \multirow{2}{*}{ Slowness } & If equal variance & 12.571 & 0.001 & 5.624 & 127 & 0.000 \\
\hline & In unequal variance & & & 5.025 & 68.479 & 0.000 \\
\hline \multirow{2}{*}{ Pedestrians } & If equal variance & 1.053 & 0.307 & -2.261 & 127 & 0.025 \\
\hline & In unequal variance & & & -2.331 & 104.999 & 0.022 \\
\hline \multirow{2}{*}{$\begin{array}{l}\text { Travel time } \\
\text { increase }\end{array}$} & If equal variance & 4.140 & 0.044 & 4.468 & 127 & 0.000 \\
\hline & In unequal variance & & & 4.184 & 78.554 & 0.000 \\
\hline \multirow{2}{*}{$\begin{array}{l}\text { Presence of } \\
\text { children in the car }\end{array}$} & If equal variance & 0.010 & 0.922 & -2.455 & 127 & 0.015 \\
\hline & In unequal variance & & & -2.466 & 97.255 & 0.015 \\
\hline
\end{tabular}


The $30 \mathrm{kph}$ zones constitute a new social object in the drivers' daily life. Many European cities have decided to implement it on their territory. They sometimes decided to generalize it. The representational valence allows individuals to defend social positions (Doise, 1986, 1992) [7] [8] towards the $30 \mathrm{kph}$. Thus, by analysing the representational valence, we can understand representations' anchoring. Most of all, we suggest taking into account the distance from the object which is specifically interesting in order to study the relationship between individuals, social objects and their representation. Spinoza (1660: p. 68) [27] said that "love born from the representation and the knowledge we have of an object; the higher and more important the object is, the stronger and more important love is" (our translation). It seems to mean the consideration of the object depends on individuals' representation. To insure a social acceptance of the $30 \mathrm{kph}$ by drivers, it appears necessary to be sure that people have a positive representation. For people with a negative representational valence, we could try to inform people in order to generate a transformation of the social representation. In this framework, there are two conceptions. The first one considers social practices are the best way to transform social representations from a structural point of view (Abric, 1994; Flament, 1987, 1994; Guimelli, 1998) [28]-[31]. We already confirmed it in the field of $30 \mathrm{kph}$ (Bordarie, 2015; Bordarie \& Gaymard, 2015a) [3] [32]. The second one is interested in communication impact and persuasion in representational dynamics (Aïssani, 1991; Gaffié \& Aïssani, 1992; Mugny, Moliner, \& Flament, 1997; Mugny, Quiamzade, \& Tafani, 2001; Roussiau \& Bonardi, 2001) [33]-[38]. Moscovici (1961) [1] described the impact of communication in the representation process. Depending on the object, the kind of information and source's credibility, the impact of communication can be different (Renard \& Roussiau, 2007; Roussiau \& Soubiale, 1996b) [39]-[41]. Furthermore, we demonstrated its relevance in the field of the 30 kph generalization in a city (Bordarie, 2015; Bordarie \& Gaymard, 2015) [6] [31]. These two conceptions clearly appear as important and relevant for government and local authorities in order to support individuals' practices change, and to insure a social acceptance of public policies.

\section{References}

[1] Moscovici, S. (1961) La psychanalyse, son image et son public. Presses Universitaires de France, Paris.

[2] Abric, J.-C. (2001) L’approchestructurale des représentationssociales: développementsrécents. Psychologie et société, 4, 81-103.

[3] Bordarie, J. and Gaymard, S. (2015) Représentationssociales et comportements à l'égard du 30km/h: pratiquesrapportées et pratiques effectives. In: Gaymard, S. and Tiplica, T., Dirs., Sécurité, éducation et mobilités: Maîtrise des risques et prévention Tome 2, L'harmattan, Paris, 151-164.

[4] Bordarie, J. and Gaymard, S. (2015) La face cachée du 30km/h: utilisationd'une technique de substitution pour mettre à jour la zone masquéed'unereprésentation. Communication affichée au Colloque International «RisquesRoutiers et Transports Durables: Usagers, Systèmes et Environnements» (RRTD 2015). Maison des Sciences Humaines, Angers.

[5] Jodelet, D. (1991) Les représentationssociales. Presses Universitaires de France, Paris.

[6] Moliner P. (1988) La représentationsocialecomme grille de lecture. Thèse de doctorat en psychologie, Université de Provence, Aix en Provence.

[7] Doise, W. (1986) Les représentationssociales: définition d’un concept. In: Doise, W. and Palmonari, A., Eds., L’étude des représentationssociales, Delachaux et Niestlé, Neuchâtel, Paris, 81-94.

[8] Doise, W. (1992) L'ancragedans les étudessur les représentationssociales. Bulletin de Psychologie, XLV, 189-195.

[9] Rouquette, M.-L. (1994) Sur la connaissance des masses. Presses Universitaires de Grenoble, Grenoble.

[10] Rouquette, M.-L. (1997) La structure et le sens des représentationssociales: réponses à quelques questions d’Alain Clémence. Textessur les représentationssociales, 6, 89-92.

[11] Abric, J.-C. and Tafani, E. (1995) Nature et fonctionnement du noyau central d'unereprésentationsociale: la représentation de l'entreprise. Cahiers Internationaux de PsychologieSociale, 28, 22-31.

[12] Dany, L. and Abric, J.-C. (2007) Distance à l'objet et représentations du cannabis. Revue internationale de psychologiesociale, 3, 77-104.

[13] Flament, C. (1999) La représentationsocialecommesystèmenormatif. Psychologie et société, 1, 29-53.

[14] Flament, C. (1999) Libertéd'opinion et limite normative dans une representation sociale: le développement de l'intelligence. Swiss Journal of Psychology, 58, 201-206. http://dx.doi.org/10.1024//1421-0185.58.3.201

[15] Gaymard, S. (2003) La négociationinterculturelle chez les fillesfranco-maghrébines: uneétude de représentationsociale. Editions L'Harmattan, Paris.

[16] Gaymard, S. (2014) The Theory of Conditionality: An Illustration of the Place of Norms in the Field of Social Think- 
ing. Journal for the Theory of Social Behaviour, 44, 229-247.

[17] Bordarie J. and Gaymard S. (2014) Influence of normative models on social representations: the case of $30 \mathrm{kph}$. Communication présentée au Colloque «The IAFOR North American Conference on Psychology \& the Behavioral Sciences 2014». Publication dans les actes du colloque, Providence Marriott Downtown, Providence.

[18] Gaymard, S. (2009) Norms in Social Representations: Two Studies with French Young Drivers. The European Journal of Psychology Applied to Legal Context, 1, 165-181.

[19] Gaymard, S. and Bessin, M. (2014) The Influence of Normative Models in the Social Representation of the Moped among Young Teenage Boys: A Pilot Study. Securitas Vialis, 17, 21-41.

[20] Gaymard, S. (2007) La représentation de la conduite chez de jeunes conducteurs: Une étude de la conditionnalité routière. Recherche Transports Sécurité, 97, 339-359. http://dx.doi.org/10.3166/rts.97.339-359

[21] Schwarz, N., Knäuper, B., Hippler, H. J., Noelle-Neumann, E. and Clark, L. (1991) Rating Scales Numeric Values May Change the Meaning of Scale labels. Public Opinion Quarterly, 55, 570-582. http://dx.doi.org/10.1086/269282

[22] Rouquette, M.L. (1995) La psychologiepolitique. Presses Universitaires de France, Paris.

[23] Verplanken, B. and Orbell, S. (2003) Reflections on Past Behavior: A Self-Report Index of Habit Strength. Journal of Applied Social Psychology, 33, 1313-1330. http://dx.doi.org/10.1111/j.1559-1816.2003.tb01951.x

[24] Nunnaly, J. (1978) Psychometric Theory. McGraw-Hill, New York.

[25] Flament, C. (2001) Pratiquessocialesetdynamique des représentations. In: Moliner, P., Ed., La dynamique des representations sociales, Presses Universitaires de Grenoble, Grenoble, 43-58.

[26] Gaymard, S. and Andrés, S. (2009) Représentations, modèlesnormatifs et compétencessociales: uneétudeexploratoiredans un lycée sensible en Espagne. Revue Internationale de Psychologie Sociale, 2, 43-69.

[27] Spinoza, B. (1660) Court Traité de Dieu, de l'homme et de la beatitude. (First translation in French by P. Janet in 1878). G. Baillière, Paris.

[28] Abric, J.-C. (1994) Pratiquessociales et représentations. Presses Universitaires de France, Paris.

[29] Flament, C. (1987) Pratiques et représentationssociales. In: Beauvois, J.-L., Joule, R.V. and Monteil, J.M., Eds., Perspectives cognitives et conduitessociales. Tome 1: Théoriesimplicites et conflitscognitifs, Delval, Cousset, 143-150.

[30] Flament, C. (1994) Aspects périphériques des représentationssociales. In: Guimelli, C., Ed., Structures et transformation des représentationssociales, Delachaux et Niestlé, Paris, 85-118.

[31] Guimelli C. (1998) Chasse et nature en languedoc. Étude de la dynamiqued'unereprésentationsociale chez les chasseurs languedociens. L’Harmattan, Paris.

[32] Bordarie, J. (2015) Représentationssociales et mobilitéurbaine durable. Thèse de doctorat, Universitéd'Angers, Angers.

[33] Aissani, Y. (1991) Etude expérimentale de la transformation d'unereprésentation sociale sous influences majoritaires et minoritaires. Thèse de Doctorat, Université de Toulouse le Mirail.

[34] Aissani, Y. (1991) Etude expérimentale de la transformation d’unereprésentation sociale dans le champ politique. Revue Internationale de PsychologieSociale, 4, 279-303.

[35] Gaffié, B. and Aïssani, Y. (1992) Confrontation idéologique et aspects symboliquesd’unereprésentationsociale. Les Cahiers Internationaux de PsychologieSociale, 13, 23-39.

[36] Mugny, M., Moliner, P. and Flament, C. (1997) De la pertinence des processusd’infuencesocialedans la dynamique des representations sociales: uneétudeexploratoire. Revue internationale de psychologiesociale, 10, 31-50.

[37] Mugny, G., Quiamzade, A. and Tafani, E. (2001) Influence sociale et dynamiquereprésentationnelle. In: Abric, J.-C., Ed., Méthoded'étude des représentationssociales, Eres, Ramonville Saint-Agne, 255-277.

[38] Roussiau, N. and Bonardi, C. (2001) Les représentationssociales: état des lieux et perspectives. Editions Mardaga.

[39] Renard, E. and Roussiau, N. (2007) Transformation des representations sociales et persuasion (modèle ELM): les effets de la crédibilité de la source. Bulletin de psychologie, 3, 211-224. http://dx.doi.org/10.3917/bupsy.489.0211

[40] Roussiau, N. and Soubiale, N. (1996) Approcheexpérimentale de la modification d'unereprésentationsociale sous l'effet de la communication d'un message. Bulletin de Psychologie, Tome XLIX. N 422, 88-99.

[41] Roussiau, N. and Soubiale, N. (1996) Etude de la transformation de la représentationsociale de l'Europe sous impact majoritaire et minoritaire. Anuario de Psicologia, 70, 19-43. 